\title{
Translation for Israeli television: the reflection of a hybrid identity
}

\author{
Rachel Weissbrod \\ Bar Ilan University
}

Broadcasting in today's world is characterized by the tensions between competing entities, including the nation-state, the agents of globalization as well as national and other minorities. This article sets out to describe these tensions as manifested in translation for Israeli TV, focusing on the relations between Hebrew - the main and most ideologically protected language of Israel - and two minority languages, Arabic and Russian. The latter represent groups that are similar in size but differ greatly in that only the former seeks acknowledgement as a national minority.

\section{Introduction: broadcasting in the era of globalization and its impli- cations for translation}

Contemporary broadcasting is characterised by tensions between several competing entities. One of them is the state which, due to the nationalism of the 19th and 20th centuries, is often the embodiment of a nation, or of one of the national groups inhabiting its territory. According to Price (1995: $11)$

[...] until the 1960s, there was virtually universal determination to maintain control of broadcasting, generally speaking, within national boundaries. If one looked at the world's radio and television systems, an essential, almost ever-present feature would be their rootedness in a single place and their exclusive relation to that place.

Processes of globalization have weakened the state and its control of the media. The main change introduced by globalization is a greater than ever "spillover of signals" (ibid.: 11). New patterns of broadcasting which make use of modern technologies, referred to by Pool (1983) as "technologies of freedom" because of the vast opportunities they open up, trespass national borders. The emblem of this new situation is the satellite dish, which makes it possible for a producer in one country to send information directly to households in another, thus bypassing not only the national broadcasting services, but also the cable systems constructed under national control (Price 1995: 14).

Just as there is a globalizing, border-obliterating trend in today's broadcasting, so there is a process of disintegration within political borders. 
National, ethnic and religious minorities which challenge the dominant national identity make their own demands on the media. However, the empowerment of minorities is not necessarily the result of the weakening of the nation-state. It might also be the consequence of a liberal policy. In the latter case, the nation-state itself is attentive to the diverse needs of its minorities and protects their rights in the media, often through legislation (ibid.: 40-41).

Translation is capable of strengthening each of the above-mentioned entities through its choice of a target language (or languages) and mode of translating - whether subtitling or re-voicing.

Translation can strengthen the national language vis-à-vis other languages used in the target culture by giving it precedence, or even exclusiveness, as a target language. It can also strengthen the national language vis-à-vis foreign languages by preferring re-voicing - either dubbing, which eliminates the original spoken dialogue completely, or voice-over, which 'covers' most of it - to subtitling. According to Danan (1991: 612), "dubbing $[\ldots]$ is an assertion of the supremacy of the national language and its unchallenged political, economic and cultural power within the nation's boundaries". Re-voicing can thus be seen as resistance to globalization, and particularly to the predominance of English, currently the main language of imported films and programs in many countries (Gottlieb 2001).

Conversely, translation may promote globalization by exposing local audiences to foreign channels and languages, as well as empower minorities by legitimizing their languages. If the mode used is subtitling, translation into more than one language may be provided, and the alternative translations may be shown on the screen at one and the same time. Since subtitling involves condensation of the original dialogue, bilingual subtitles appearing simultaneously mean a double condensation. However, the optional use of teletext, and nowadays of digital broadcasting, if available, provides a solution to this problem by making it possible to select a target language. In fact, digital broadcasting allows for the use of re-voicing as the mode of translation while still providing spectators with the option of choosing a target language.

The choice of target language(s) and translation mode(s) depends on norms (Delabastita 1989), which are supposedly a major constraint on translation in general (Toury 2000). These norms do not develop independently of economic considerations. For instance, countries with a small population may prefer the less expensive mode, subtitling, even though it does not serve their national interests (Danan 1991). Some options, such as letting the customers select the target language and the mode of translation, cannot be realised unless modern technologies are available. However, ideological considerations are involved too, and in any case, even an economically motivated or technologically driven preference is not necessarily devoid of ideological and political implications.

Against this background, the present paper sets out to analyze translation for Israeli television in its two historical phases, from the late 1960s 
to the early 1990s and from the 1990s on, and to find out whether and in what ways it serves the national cause, and what the implications are for Israel's largest minorities - Israeli Arabs and newly arrived immigrants. Special consideration will be given to the immigration from the former Soviet Union (FSU) in the 1990s.

\section{Early Israeli Television: Nationalism, Statehood and Their Manifes- tations in Translation}

The establishment of the State of Israel in 1948, following a UN resolution, realised the Zionist aspiration of establishing a national home for the Jewish people. As a nation-state, Israel cultivated Hebrew, the language which best represented national feelings, and gave precedence to Hebrew culture over other sub-cultures. Notwithstanding the melting-pot policy applied to various cultural areas including the media (Spolsky \& Shohamy 1999, Kuzar 2001, Even-Zohar 2005), the predominance of Hebrew was not complete. The immigrants who populated Israel used a variety of languages, and as Even-Zohar (2005: 5) puts it, "Hebrew did not drive the immigrants' languages out of the homes of people". Moreover, the policy makers themselves acknowledged the immigrants' needs. Israeli radio, which had started to operate in 1936 under British Mandatory Rule, initially broadcast on two channels - one in Hebrew and another devoted to programs for immigrant groups in their own languages, including Yiddish, Ladino, Russian, Polish, Hungarian, Rumanian and more (Liebes 2003: 27). Special broadcasts were addressed to the Arab minority - Palestinians who had not left the country during the 1948 war and their descendants, and to potential audiences in the neighboring Arab countries. Broadcasting in Arabic served political goals, but it also reflected the status of Arabic, since the British Mandate, as an official language side-by-side with Hebrew.

Notwithstanding the acknowledgement of Arabic and the immigrants' languages, Hebrew culture was the main concern of policy makers. In fact, concern for its future was one of the reasons why the establishment of an Israeli television was postponed till the late 1960s:

The bona fide ideological objections of the political leadership to television $[\ldots]$ were that it would subvert the effort to renew Hebrew culture, undermine reading, and Americanize and secularize society (as argued by religious politicians) (ibid.: 30).

In the absence of local television, only Israeli Arabs and Jewish immigrants from Arab countries used to install an antenna and receive broadcasts from the neighboring Arab countries. Israeli television was eventually inaugurated in 1968, following the Six Day War. At least one of the motives for establishing it was the need to address the Palestinians in the occupied territories who were exposed to Arab broadcasts from the 
neighboring countries. From the 1960s to the 1990s, it consisted of one public channel, Channel 1, which operated under the Israel Broadcasting Authority Law of 1965 . The law, updated in 1968 to accommodate the introduction of the new medium, dictated that television cultivate Hebrew culture, advance national integration, preserve Jewish heritage and broadcast in Arabic "for the Arabic-speaking population, and for the advancement of peace with the neighboring countries" (Liebes 2003: 30).

Considering the insistence on national values and statehood, Israeli television might have been expected to use re-voicing as the main mode of translation. However, economic considerations had the upper hand, and Israel chose subtitling, thus joining other countries with a small population. ${ }^{1}$ Subtitles were usually in both Hebrew and Arabic, and since broadcasting was analogue, they appeared simultaneously on the screen. However, in special cases, when the original was considered important or hard to condense (Nir [1984] gives The Muppet Show as an example), translation was provided solely into Hebrew. The concern for the national language was also expressed in the stylistic norms. The register was often elevated compared with the original. Slang and vulgar phrases were avoided, especially in translations for children, for educational reasons. When slang and vulgarisms did find their way into the translation, they were put in quotation marks, indicating that their inclusion was exceptional. The use of foreign borrowed words was shunned too, even when they were more familiar to the public than their Hebrew substitutes. Thus the captions often contained newly coined Hebrew words with which the public was not acquainted. When translators deviated from the norms, either intentionally or by mistake, their translation was corrected by language editors (Nir 1984: 88-89).

Dubbing was limited to children's films and programs, at first only animated ones and later those with live actors as well. Politicians tried, in vain, to extend the use of dubbing by proposing laws that would make it compulsory. One such attempt was made in 1980 by Moshe Shamir, a prominent author and (at that time) a member of the Israeli parliament, the Knesset. The proposed law was attacked by Menachem Perry (1980: 7, translation RW), a leading literary researcher and editor, on aesthetic grounds:

[...] the film's sound is part of its composition. The director and actor have said what they wanted to say by means of a particular manner of speaking too. Actors perform with their voice, not only with their hands. Such a situation, of "the voice is the voice of Jacob, but the hands are the hands of Esau" amounts to cutting out part of an artistic work and throwing it into the wastebasket. It is like printing two chapters from a novel by Moshe Shamir and pretending that it is the entire novel. It is like falsifying the weight of a product. 
It is noteworthy that in his defense of subtitling, Perry ignored the fact that this mode of translation was a problem not only from a national point of view but also from the perspective of social solidarity. According to Nir (1984: 93), about $20 \%$ of the Israeli Jewish population in that decade, including new immigrants and poorly educated people, could neither understand the original dialogue of imported films and programs (which formed the majority of broadcasts and were usually in English) nor read the Hebrew subtitles. The inaccessibility of television to the poorly educated was especially problematic because watching it constituted their main, if not their only form of entertainment (ibid.: 93).

\section{Israeli Television since the 1990s: Multiculturalism, Commercialism, and Implications for Translation}

\section{1. The Rise of Multi-Channel Commercial Television}

Since the early 1990s, Israeli television has undergone drastic changes (Caspi \& Limor 1999). Deriving from processes of privatization and a weakening of state control over the media, they reflect the impact of globalization on Israel. The monopoly of Channel 1 ended in 1990 when several companies, only recently merged into one (Hot), started to broadcast via cable to subscribers. Since 2000 Hot is rivaled by Yes, which offers television to subscribers via satellite. Before the new millennium, Israelis could install a satellite dish and watch non-local channels. But only a local company could answer the need for broadcasts in Hebrew, both locally produced and translated. Hot and Yes differ from Channel 1 in that they give priority to commercial considerations, though they too are subject to regulatory constraints.

In addition to cable and satellite TV, Israel currently has two channels financed by commercials: Channel 2, inaugurated in 1993, and Channel 10, inaugurated in 2002. Like Hot and Yes, they are commercially oriented, though subject to the Second Radio and Television Authority Law of 1990.

\subsection{The Multilingualism of Contemporary Israeli Television}

The rise of multi-channel commercial television has implications for the status of Hebrew vis-à-vis other languages. In accordance with Price's claim regarding the post-national era in the history of television, Israeli spectators are nowadays exposed to a plentitude of channels in a variety of languages. In January 2007 the digital basic package of the leading network, Hot, included 70 channels in 10 different languages, including 10 in Arabic, 7 in Russian, 2 in French, 3 in German, 2 in Italian, 2 in Turkish, 1 in Hungarian, 1 in Spanish and 1 in Hindi. This offer is determined by the company's commercial interests and is subject to daily changes (e.g., 
channels are removed from the basic package or not offered anymore). Though the exposure to a variety of languages can be regarded as a threat to the national language, it can also be interpreted as a counterbalance to the increasing power of English and American culture (Epstein \& Kheimets 2006). The impact of the latter is manifest not only in the availability of American and British channels but also in the large share of Englishspeaking films and programs on the local channels.

In addition to the broadcasting of non-local channels, the cable and satellite TV companies also provide local channels in languages other than Hebrew. These include Russian, Ukrainian, Georgian and Amharic - the languages of the largest groups of immigrants since the 1990s. (Attempts to produce a local Arabic channel have so far failed). These channels supplement single non-Hebrew programs which are broadcast on both the public and the commercial channels (as mentioned, the latter, too, are subject to regulation). Commercialism on the one hand and governmental regulation on the other have thus turned Israeli television into a site of multilingualism, as opposed to the insistence on Hebrew in previous decades. Unfortunately, it can be enjoyed mainly by those who can afford it, namely cable and satellite subscribers, and more specifically subscribers who pay extra money for channels which are not included in the basic package.

\subsection{Multilingualism as Manifested in TV Translation}

\subsubsection{The Dominance of Hebrew}

In this new multilingual situation, Israel is still, to a large extent, a subtitling country, and the main target language is Hebrew. Hebrew translation accompanies both imported films and programs on the local channels, and broadcasts of some popular foreign channels such as BBC Prime, National Geographic and Hallmark. Moreover, a new law enacted in 2006 on behalf of the deaf and hearing-impaired dictates that Hebrew subtitles also accompany locally produced Hebrew programs.

The language used in the Hebrew subtitles has changed significantly. Slang and vulgarisms in the original dialogue no longer pose a problem. The norm described by Nir (1984) has almost vanished. In an examination of the translation of films based on Shakespeare's plays (Weissbrod 2006), a striking difference was found between Channel 1 and the commercial channels. A translation of Othello (Miller 1981) made for Channel 1 in 1992 was abundant with elements of elevated language such as rare grammatical forms, idioms rooted in old canonised Hebrew texts and Aramaic words and collocations which had infiltrated Hebrew in the past (e.g., be-matuta, meaning 'please', rather than the Hebrew be-vakasha; and tsafra tava, meaning 'good morning', rather than the Hebrew boker tov). In the commercial channels, elevated language was used only when the translation was based on a pre-existing literary translation. 
Apart from the dominance of Hebrew as a target language, current TV translation serves national interests in that, unlike the growing use of non-Hebrew translation in adults' films and programs (see below), dubbing, which is still limited to children's films and programs, is always in Hebrew. This means that the younger generation of TV viewers is being raised on Hebrew (as long as they watch Israeli channels). In recent years, children's films have become available in both dubbed and subtitled versions (for a description of a similar situation in Greece, see Karamitroglou 2001). My examination of the dubbed and subtitled Hebrew versions of Shrek (Adamson \& Jenson 2001) leads to the conclusion that the previous language norm has weakened even in dubbing, which is specifically addressed to younger children and is therefore more likely to be constrained by educational dictates. Its remnants, however, can still be observed, e.g. in the decision to replace the vulgarism "broad", in referring to a lady (SnowWhite, in this case), with the less offensive na'ara (a young girl). The main difference between the two versions concerns domestication, which is far more conspicuous in the dubbed version. For instance, the original allusion to an English children's song, "The Muffin Man", has been replaced with an allusion to a popular Hebrew children's song, Uga Uga (meaning in this context "Let's dance in a circle"). Freed from the previous language norm, the translator has used slang, but the slang too is markedly Israeli, e.g. in the way it combines English and Arabic words ('akhla deal' combines the Arabic akhla signifying satisfaction with the English 'deal'; together they mean 'a sucessful transaction'). Such manipulations, probably meant to adapt the film for young Israeli children, affirm Danan's claim (1991: 612), that subtitling is a source-oriented mode of translation whereas dubbing is target-oriented.

\subsubsection{Russian and Arabic}

While dubbing plays a role in ensuring the position of Hebrew as the language of the younger generation, the increasing use of Russian translation in films and programs for adults is a catalyst in the transformation of Israel into a multilingual, multicultural country. Russian translation is provided in two forms. The first is subtitles, which are either added to the Hebrew ones or offered as an option. The second is voice-over, a mode of AVT commonly used in Eastern Europe (Grigaravičiūtè \& Gottlieb 1999; Orero 2004). Its use in translating for immigrants from the FSU can be explained by its low cost - in comparison with full dubbing - due to the fact that no synchronization of the voice and lip-movement is attempted. However, it also reflects the view of producers, consolidated by research (Danan 1991), that spectators tend to favor the mode of translation to which they are already accustomed. Since the majority of Israeli TV spectators are Hebrew speakers, Russian voice-over in all channels (except the Russian-speaking Channel 9) is optional; this has been made feasible by the gradual shift from analogue to digital broadcasting. 
The availability of Russian translation is partly due to legislation. The commercial channels, 2 and 10, operate under the Second Israeli Broadcasting Authority law which dictates that at least 5\% of their broadcasts must be either produced in, or translated into, Russian (in addition to 5\% in Arabic; see Schechter [n.d.]. But the growing use of Russian as a target language cannot be explained by legislation alone. A more fitting explanation is the high percentage of immigrants from the FSU among TV spectators, including the cable and satellite subscribers ${ }^{2}$. Their large share in the audience is probably the reason why Channel 10 has decided to add Russian translation to all its daily broadcasts after 17:00 o' clock $^{3}$.

In comparison with Russian, the position of Arabic as a target language is marginal, and the above-mentioned law can hardly help to change it. The satellite company, which provides Russian translation in both its entertainment and educational channels, offers Arabic subtitles only in its cinema channels. The cable company offers even less. In fact, Arabic and Bedouin villages in the periphery often lack the infrastructure needed for cable TV. According to a survey conducted by the Israeli Central Bureau of Statistics in 2005, 96.9\% of Arab households, compared with $90.6 \%$ of Jewish households, have television sets. (The gap can be explained by the fact that ultra-Orthodox Jews refrain from watching TV). But when it comes to multi-channel television, only $13.4 \%$ of Arab households, compared with $77.4 \%$ of Jewish households, are subscribers of the cable and satellite companies ${ }^{4}$. These data can explain the scarcity of Arabic translation on the cable and satellite channels. Channels 1 and 33 the latter is the satellite channel of the Israel Broadcasting Authority which has replaced Channel 1 as the main site of broadcasting in Arabic - provide Arabic translation. But they are low-rating channels which cannot counteract the tendency of Israeli Arabs to install a satellite dish and receive non-coded broadcasts from the Arab world free of charge.

When translation into Arabic is not totally absent, its marginality is apparent in the translational norms - in making do with mediated translation. In an examination of one episode from the series "The Simpsons", it has been found that the Arabic translation, like the Hebrew one, is free of censorship. It does not omit references to sex and sacrilegious expressions which the dubbed series, produced for the Arab world by MBC (Middle East Broadcasting Center), consistently evades (Atamna 2006). However, it is a literal translation of the Hebrew version, which misses many of the puns and preserves neither the wittiness of the original nor that of the more adequate Hebrew translation ${ }^{5}$. For instance, the original "make your cubicle into a you-bicle" became, in Hebrew, Tahafokh et ha-ta shelkha la-ata shelkha ('make your cubicle into your you'). The Arab translator missed the pun because he interpreted the ambiguous Hebrew word $t a$ as a cell (in biology) rather than a cubicle.

The two minority groups referred to, Israeli Arabs (not including the inhabitants of the territories occupied since 1967), and the immigrants who 
came to Israel following the collapse of the Soviet Union in the 1990s, are similar in size: each forms about $20 \%$ of the Israeli population of 7 million ${ }^{6}$. However, they greatly differ in other respects. The immigration of the 1990s is unique in that it has been motivated by economic considerations and a growing anti-Semitism in Eastern Europe rather than Zionist zeal. Deeply rooted in their cultures of origin, and free from the constraints of the melting-pot policy of previous years, the immigrants have established a "cultural autonomy" consisting of journals, publishing houses, educational institutions and cultural events in Russian. However, they regard themselves as a cultural rather than a national minority. Notwithstanding their heterogeneity, most of them share with the majority of Israelis their religion, their collective memories as members of the Jewish people and their sentiments for Hebrew. Broadcasts in Russian, which possibly contribute to their separateness, also make easier their integration into Israeli society (Elias 2005). Israeli Arabs, on the other hand, regard themselves as a national minority (Schechter [n.d.], Pinto 2007). Their ability to communicate with Israeli Jews in Hebrew does not eliminate their aspiration for Arabic, which plays an important role in constructing their national identity, to be truly acknowledged as one of the languages of Israel. This is evident in appeals submitted by Adalah ('Justice' in Arabic), the Legal Center for Arab Minority Rights in Israel, which demands the implementation of the laws designating Arabic as an official language ${ }^{7}$. In this situation, the marginality of Arabic compared with Russian as a target language in translation for Israeli television is a manifestation of discrimination, even if it does stem from commercial rather than ideological considerations.

\section{Conclusion}

Since its establishment in the late 1960s, Israeli television has changed drastically. Liebes (2003), who examines its evolution against the backdrop of the collapse of the peace talks with the Palestinians, is critical about the direction it has been taking:

[Israeli] TV has managed to transform itself, together with its constituency, from a BBC-like public broadcasting system, intent on national identity and dialogue with the Arabs, into a multi-channel system, featuring American values of individualization, privatization, and a premature sense of "normalcy" that followed the Oslo Agreement (ibid.: xi).

Her complaint is at least partly applicable to TV translation as well. In previous years, bilingual subtitles in Hebrew and Arabic expressed the concern for the national language, on the one hand, and an acknowledgement of the Arab minority, on the other. The present approach, 
on the contrary, legitimises multilingualism as long as it proves profitable. As a result, the needs of one minority group, those of the immigrants from the FSU, are better attended to than those of another minority group, similar in size - that of Israeli Arabs. In light of their status as citizens of the State of Israel, their national distinction and the status of their language as an official one, their neglect by Israeli television can hardly be justified by the wealth of broadcasts accessible from the Arab world.

\section{Bibliography:}

Atamna, Wijdan (2006). “Dubbing 'The Simpsons' for the Arab World”. Ramat Gan: Bar Ilan University. [A term paper in Hebrew.]

Caspi, Dan \& Yehiel Limor (1999). The In/Outsiders: Mass Media in Israel. Cresskill, NJ: Hampton Press.

Danan, Martine (1991). "Dubbing as an Expression of Nationalism". Meta 36(4), 606-614.

Delabastita, Dirk (1989). "Translation and Mass-Communication: Film and TV Translation as Evidence of Cultural Dynamics". Babel 35(4), 193-218.

Elias, Nelly (2005). Media Uses as Integration Strategy: The Case of the Immigrants from the FSU in Israel. Tel Aviv: Chaim Herzog Institute for Communication, Society and Politics. [In Hebrew.]

Epstein, Alek D. \& Nina G. Kheimets (2006). "Between Globalization and Localization: The Linguistic Diversity of the Israeli Mass-Media". Paper presented at the 5th Conference of the Israeli Association for the Study of Language and Society (The Open University of Israel, 4 June 2006).

Even-Zohar, Itamar (2005). "Who is Afraid of the Hebrew Culture?". Papers in Culture Research. On line at: http://www.tau.ac.il/ itamarez/ (accessed on 5 December 2007).

Galily, Lily (2004). "Imperyat Ha-Televizya Be-Russit" ("The Empire of Television in Russian”). Ha'aretz, 26 Sept. [In Hebrew.]

Gottlieb, Henrik (2001). "Anglicisms and TV Subtitles in an Anglified World". Y. Gambier \& H. Gottlieb (eds) (2001). (Multi)Media Translation. Amsterdam/Philadelphia: Benjamins, 249-258.

Grigaravičiūtė, Ieva \& Henrik Gottlieb (1999). "Danish Voices, Lithuanian Voice-Over: The Mechanics of Non-Synchronous Translation". Perspectives 7(1), 41-80.

Karamitroglou, Fotios (2001). "The Choice between Subtitling and Revoicing in Greece: Norms in Action". Target 13(2), 305-315.

Kuzar, Ron (2001). Hebrew and Zionism: A Discourse Analytic Cultural Study. Berlin: Mouton de Gruyter.

Liebes, Tamar (2003). American Dreams, Hebrew Subtitles: Globalization from the Receiving End. Cresskill, NJ: Hampton Press.

Nir, Raphael (1984). "Linguistic and Sociolinguistic Problems in the Translation of Imported TV Films in Israel". H.B Beardsmore (ed.) (1984). Language and Television. Berlin: Mouton de Gruyter. Special Issue of International Journal of the Sociology of Language 48, 81-97.

Orero, Pillar (2004). "The Pretended Easiness of Voice-over: Translation of TV Interviews". Jostrans 2, 76-96.

Perry, Menachem (1980). "Enemy of the Hebrew Letter". Siman Kri'a 11, 7. [In Hebrew].

Pinto, Meital (2007). "On the Intrinsic Value of Arabic in Israel - Challenging Kymlicka on Language Rights". Canadian Journal of Law and Jurisprudence XX(1), 143-172.

Pool, Ithiel de Sola (1983). Technologies of Freedom. Harvard, Mass.: Belknap Press.

Price, Monroe E. (1995). Television: The Public Sphere and National Identity. Oxford: Clarendon Press.

Schechter, Amit (n.d.). "'...And the Sojourner Who is Among You' - Media Legislation and the Rights of the Arabic-Palestinian Minority in Israel: A Critical Overview". [In Hebrew]. http://www.personal.psu.edu/ams37/the\%20stranger\%20full\%20version.htm. (last visited on 31 January 2007).

Spolsky, Bernard \& Elana Shohamy (1999). The Languages of Israel: Policy, Ideology and Practice. Clevedon: Multilingual Matters. 
Statistical Abstract of Israel 1969 (No. 20) published by the Israeli Central Bureau of Statistics. http://www1.cbs.gov.il/reader (accessed on 15 February, 2007).

Statistical Abstract of Israel 2005 (No. 56) published by the Israeli Central Bureau of Statistics. http://www1.cbs.gov.il/reader (accessed on 15 February 2007).

Toury, Gideon (2000). "The Nature and Role of Norms in Literary Translation". L. Venuti (ed.) (2000). The Translation Studies Reader. London/New York: Routledge, 198-211.

Weissbrod, Rachel (2006). "Hebrew Subtitles of Films Based on Shakespeare's Plays". R. BenShahar \& G. Toury (eds) (2006). Hebrew - A Living Language: Studies on the Language in Social and Cultural Contexts, Vol. 4. Tel Aviv: The Porter Institute for Poetics and Semiotics/Hakibbutz Hameuchad, 127-140. [In Hebrew].

\section{Filmography}

Shrek (2001)

USA, DreamWorks Animation

Dir. Andrew Adamson \& Vicky Jenson

Subtitling: Elrom Studios

Dubbing: Mirit Shem-Or

Othello (1981)

UK, BBC

Dir. Jonathan Miller

Subtitling: Avigail Neubach.

1 In 1968, the Israeli population numbered three million. Based on Statistical Abstract of Israel 1969 (No. 20) published by the Israeli Central Bureau of Statistics.

http://www1.cbs.gov.il/reader (last visited on 15 February 2007).

2 According to a press report (Galily 2004), 94\% of Russian-speaking households - compared to $75 \%$ of veteran Israeli households - have access to multi-channel television. Noah Atlan of Yes reported to me (in May 2006) that $25 \%$ of the company's subscribers are Russian-speaking.

3 The channel's policy is stated in its site: http://10.tv/. (last visited on 31January 2007).

4 The source of data is a special report of the Israeli Central Bureau of Statistics (to be published in 2007). I thank Yafit Alfandary of the Bureau for access to the information.

5 The episode which has been examined is no. 306 from the 14th season. It was first aired on March 16, 2003 and broadcast on Channel 1 on September 9, 2006. I thank Wijdan Atamna for her help in carrying out the triple comparison.

6 Based on Statistical Abstract of Israel 2005 (No. 56) published by the Israeli Central Bureau of Statistics. http://www1.cbs.gov.il/reader (last visited on 15 February 2007)

7 Information on Adalah is available on line at http://www.adalah.org/eng/ (last visited on 13 February 2007). 